\title{
Sarcopenia and body mass index predict sunitinib-induced early dose-limiting toxicities in renal cancer patients
}

\author{
O Huillard ${ }^{1}$, O Mir ${ }^{*}, 1$, M Peyromaure ${ }^{2}, C_{\text {Tlemsani }}{ }^{1}, J_{\text {Giroux }}{ }^{1}$, P Boudou-Rouquette ${ }^{1}$, S Ropert ${ }^{1}$, \\ $\mathrm{N}$ Barry Delongchamps ${ }^{2}, \mathrm{M}^{2}$ Zerbib $^{2}$ and F Goldwasser ${ }^{1}$ \\ ${ }^{1}$ CERIA (Centre for Research on Angiogenesis Inhibitors), Department of Medical Oncology, Teaching Hospital Cochin, AP-HP, \\ University Paris Descartes, 27, rue du Faubourg Saint Jacques, Paris F75014, France and ${ }^{2}$ Department of Urology, Teaching \\ Hospital Cochin, AP-HP, University Paris Descartes, 27, rue du Faubourg Saint Jacques, Paris F75014, France
}

Background: Little is known on factors predicting sunitinib toxicity. Recently, the condition of low muscle mass, named sarcopenia, was identified as a significant predictor of toxicity in metastatic renal cell cancer (mRCC) patients treated with sorafenib. We investigated whether sarcopenia could predict early dose-limiting toxicities (DLTs) occurrence in mRCC patients treated with sunitinib.

Methods: Consecutive mRCC patients treated with sunitinib were retrospectively reviewed. A DLT was defined as any toxicity leading to dose reduction or treatment discontinuation. Body composition was evaluated using CT scan obtained within 1 month before treatment initiation.

Results: Among 61 patients eligible for analysis, 52.5\% were sarcopenic and $32.8 \%$ had both sarcopenia and a body mass index $(\mathrm{BMI})<25 \mathrm{~kg} \mathrm{~m}^{-2}$. Eighteen patients (29.5\%) experienced a DLT during the first cycle. Sarcopenic patients with a BMl $<25 \mathrm{~kg} \mathrm{~m}^{-2}$ experienced more DLTs $(P=0.01$; odds ratio $=4.1 ; 95 \% \mathrm{Cl}$ : $(1.3-13.3))$, more cumulative grade 2 or 3 toxicities $(P=0.008)$, more grade 3 toxicities $(P=0.04)$ and more acute vascular toxicities $(P=0.009)$.

Conclusion: Patients with sarcopenia and a $\mathrm{BMl}<25 \mathrm{~kg} \mathrm{~m}^{-2}$ experienced significantly more DLTs during the first cycle of treatment.

Renal cancer accounts for more than 64000 new cases per year in the Unites States, and causes approximately 13500 deaths yearly (Siegel et al, 2012). Worldwide incidence and mortality rates are rising at approximately 2-3\% per decade (Gupta et al, 2008). Sunitinib (Sutent; Pfizer, New York, NY, USA) is an orally active, multi-targeted inhibitor of VEGFR1-3, PDGFR, KIT, FLT3, CSF-1 and RET (Chow and Eckhardt, 2007), approved for the treatment of metastatic renal cell cancer (mRCC; Motzer et al, 2007). Importantly, sunitinib-induced toxicities (mainly diarrhoea, handfoot syndrome, fatigue and hypertension) may limit the patient's ability to receive full-dose treatment. In the sunitinib arm of the pivotal phase III trial, these toxicities resulted in dose reductions in
$50 \%$ and treatment termination in $19 \%$ of the patients (Motzer et al, 2009).

Little is known on factors predicting sunitinib toxicity. Polymorphisms in CYP3A5 (rs776746) might identify a subset of patients prone to toxicity-related dose reductions (Garcia-Donas et al, 2011). However, these polymorphisms are not routinely assessed in daily practice.

Recently, the condition of low muscle mass, named sarcopenia (Cruz-Jentoft et al, 2010; Fearon et al, 2011), has been studied in cancer patients, in whom sex-specific cut-off values based on mortality risks have been determined (Prado et al, 2008). Sarcopenia is a significant predictor of toxicity in mRCC patients

*Correspondence: Dr O Mir; E-mail: olivier.mir@cch.aphp.fr

Part of this work has been presented as an abstract at the ASCO 2011 Annual Meeting (J Clin Oncol 29: 2011 (suppl; abstr e15094)).

Received 5 October 2012; revised 14 January 2013; accepted 19 January 2013; published online 5 March 2013

(C) 2013 Cancer Research UK. All rights reserved 0007-0920/13 
treated with sorafenib (an orally active multi-kinase inhibitor that targets BRAF, RET, PDGFR-b, VEGFR-1 and VEGFR-2 (Wilhelm et al, 2006)), in particular those with a body mass index $(\mathrm{BMI})<25 \mathrm{~kg} \mathrm{~m}^{-2}$ (Antoun et al, 2010a). As well, sarcopenia predicts treatment-induced toxicity in hepatocellular carcinoma patients treated with sorafenib (Mir et al, 2012).

The purpose of the present analysis was to investigate whether sarcopenia could predict the occurrence of early dose-limiting toxicities (DLTs) in mRCC patients treated with sunitinib. We hypothesised that an increased toxicity would be observed in sarcopenic patients.

\section{MATERIALS AND METHODS}

Participants. We performed a retrospective, electronical, medical record review of all consecutive mRCC patients treated with sunitinib in our institution from June 2006 to March 2012.

Ethics. The study was approved by the local ethics board according to good clinical practice and applicable laws, and the declaration of Helsinki.

Treatment, toxicity and activity assessment. Adult mRCC outpatients received sunitinib at a starting dose of $50 \mathrm{mg}$ per day, 4 weeks/6, $37.5 \mathrm{mg}$ continuous daily dosing (CDD) or $25 \mathrm{mg}$ CDD according to their Eastern Cooperative Oncology Group performance status (ECOG PS) and co-morbidities, at the discretion of the treating physician, as described by other authors (Escudier et al, 2009; Barrios et al, 2012). Toxicity was assessed at each visit, every 2 weeks (or before if clinically indicated) during the first cycle, then monthly.

In the case of grade 3 or 4 toxicity according to the National Cancer Institute Common Terminology Criteria v3.0, sunitinib was discontinued, except for patients with grade 3 hypertension in whom antihypertensive drugs were introduced according to current guidelines (Izzedine et al, 2009). Depending on toxicity resolution, sunitinib was resumed at full dose or at decreased doses, or permanently discontinued, at the discretion of the treating physician.

A DLT was defined as any toxicity leading to a dose reduction, temporary or permanent discontinuation of treatment. Following the design of a previous study (Prado et al, 2009), only DLTs occurring during the first cycle of treatment were examined for the present analysis. A cycle of treatment was determined as a period of 6 weeks.

Treatment activity was assessed every two cycles by CT scan, or before if clinically indicated, according to RECIST v1.0 (Therasse et al, 2000).
Anthropometric measurements. Weight was measured with a medical balance beam scale, and height was measured with a stadiometer. The BMI was calculated (weight $(\mathrm{kg}) / \mathrm{height}^{2}\left(\mathrm{~m}^{2}\right)$ ) and the World Health Organization categories were used: underweight, $\quad \mathrm{BMI}<18.5 ;$ normal, $18.5 \leqslant \mathrm{BMI} \leqslant 24.9$; overweight, $25 \leqslant \mathrm{BMI} \leqslant 29.9$; obesity, $\mathrm{BMI} \geqslant 30$. Body surface area (BSA) was calculated using the Mosteller formula: BSA $\left(\mathrm{m}^{2}\right)=(($ height $(\mathrm{cm}) \times$ weight $(\mathrm{kg})) / 3600)^{1 / 2}$.

Image analysis. Body composition was evaluated by assessing muscle tissue areas on CT-scan images, as previously described (Heymsfield et al, 1997; Mitsiopoulos et al, 1998). CT scans had been performed for diagnostic or follow-up purposes within no more than 30 days before initiation of sunitinib. Images were analysed using ImageJ software v1.42q (National Institutes of Health, http://rsb.info.nih.gov/ij). The third lumbar vertebra (L3) was chosen as a standard landmark, as previously described (Antoun et al, 2010a). Muscles were identified based on their anatomic features, and the structure of those specific muscles was quantified based on pre-established thresholds of skeletal muscle tissue ( -29 to +150 Hounsfield units; Mitsiopoulos et al, 1998). Cross-sectional areas $\left(\mathrm{cm}^{2}\right)$ of the sum of all of these muscles were computed and the mean value for two consecutive images was computed for each patient. These values were normalised for stature (Mourtzakis et al, 2008; Prado et al, 2008) and expressed in units of $\mathrm{cm}^{2} \mathrm{~m}^{-2}$. The sex-specific cutoff values for sarcopenia $\left(55.4 \mathrm{~cm}^{2} \mathrm{~m}^{-2}\right.$ for males and $38.9 \mathrm{~cm}^{2} \mathrm{~m}^{-2}$ for females) determined in cancer patients were used as done by others in mRCC patients (Antoun et al, 2010a). The total lumbar-skeletal muscle cross-sectional area is linearly related to the whole-body muscle (Shen et al, 2004; Mourtzakis et al, 2008) and the total lean body mass (LBM) was estimated from muscle cross-sectional areas as described by Mourtzakis et al (2008): LBM $(\mathrm{kg})=(0.30 \times$ (skeletal muscle area at L3 using CT $\left.\left.\left(\mathrm{cm}^{2}\right)\right)+6.06\right)$. As the body composition analysis was done a posteriori, treating physicians were blinded to patients' body composition status (sarcopenic or not).

Statistical analysis. Prevalence of toxicity was compared using Fisher's exact test, and Mann-Whitney's test was used for the comparison of continuous variables. All $P$-values were two-sided, and the level of significance was $P<0.05$. Multivariate analysis of factors predicting early DLTs was conducted using logistic regression with 3000 bootstrap iterations, including only factors predicting the occurrence of DLTs with a $P$-value $<0.05$ by univariate analysis. Progression-free survival (PFS) and overall survival (OS) were measured from the date of first treatment administration to the date of disease progression or death for the former, and the date of death for the latter. Kaplan-Meier

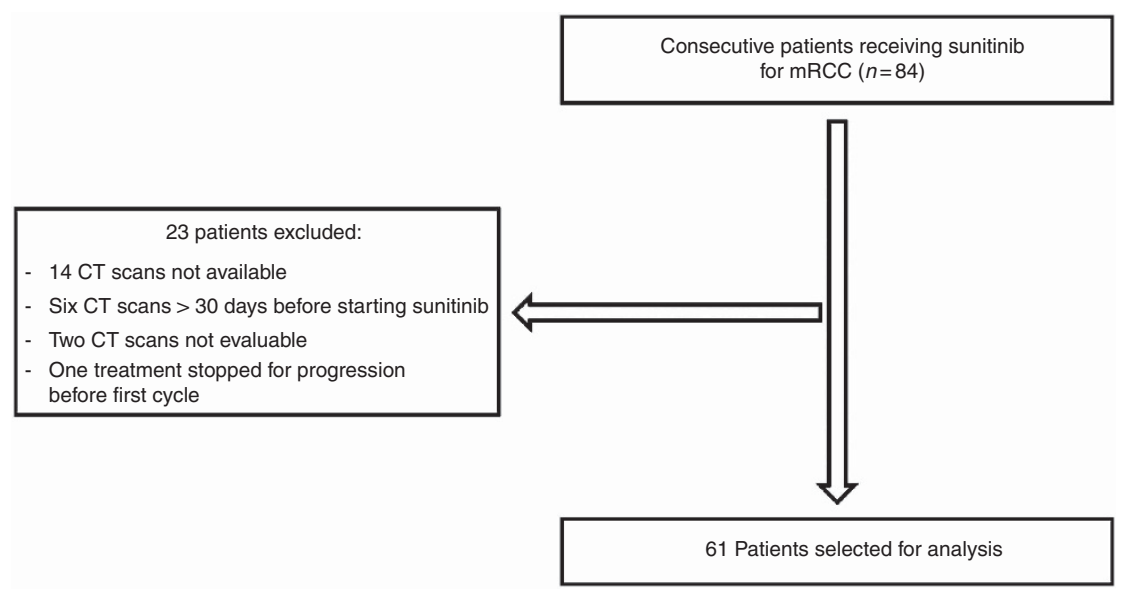

Figure 1. Patients selection for analysis. 
estimates of the distribution of times from baseline to outcome were computed, and the groups were compared using the log-rank test. Calculations were performed with NCSS 2007 software (NCSS, Kaysville, UT, USA).

\section{RESULTS}

Patients' characteristics. From June 2006 to March 2012, 84 mRCC patients received sunitinib, among which 61 (73\%) met all criteria for study analysis (Figure 1).

Baseline characteristics of patients treated with sunitinib are presented in Table 1 . Briefly, 32 patients (52.5\%) were sarcopenic and $20(32.8 \%)$ were sarcopenic, and had a BMI $<25 \mathrm{~kg} \mathrm{~m}^{-2}$. The variables needed to assign a Memorial Sloan Kettering Cancer
Center (MSKCC) risk score were missing for 11 patients, and those needed to assign a Heng score were missing for 15 patients. Some patients could be correctly assigned even with some missing data; for the others the most likely values were derived.

Sunitinib toxicity. Eighteen patients (29.5\%) experienced a DLT during the first cycle of treatment (Table 2). In all cases but two, patients had multiple toxic effects of grade 2 and/or 3 . Sunitinib was discontinued and resumed either at the same dose in three cases $(16.5 \%)$ or at a lower dose in eight cases $(44.5 \%)$. For the seven remaining patients (39\%), sunitinib was permanently discontinued. Table 2 shows therapy adjustments and the duration of subsequent sunitinib treatment after the occurrence of a DLT (median for the whole cohort: 31 weeks, range 6-150). Sunitinib was resumed in $40 \%$ of patients with sarcopenia and low BMI (for a median duration of 33 weeks, range 16-85), and in $75 \%$ of

\section{Table 1. Baseline characteristics of patients treated with sunitinib}

\begin{tabular}{|c|c|c|c|}
\hline Characteristics & Males $(n=38)$ & Females $(n=23)$ & Total $(n=61)$ \\
\hline Age (years), median (range) & $60(29-83)$ & $59(30-79)$ & $60(29-83)$ \\
\hline \multicolumn{4}{|l|}{ ECOG PS, $\boldsymbol{n}(\%)$} \\
\hline $\begin{array}{l}0 \\
1 \\
\geqslant 2\end{array}$ & $\begin{array}{l}14(36.8) \\
19(50) \\
5(13.2)\end{array}$ & $\begin{array}{r}5(21.7) \\
12(52.2) \\
6(26.1)\end{array}$ & $\begin{array}{l}19(31.2) \\
31(50.8) \\
11(18)\end{array}$ \\
\hline \multicolumn{4}{|l|}{ Metastatic sites, $\mathbf{n}(\%)$} \\
\hline $\begin{array}{l}1 \\
2 \\
3 \\
\geqslant 4\end{array}$ & $\begin{array}{r}16(42.1) \\
8(21.1) \\
7(18.4) \\
7(18.4)\end{array}$ & $\begin{aligned} 11 & (47.8) \\
6 & (26.2) \\
5 & (21.7) \\
1 & (4.3)\end{aligned}$ & $\begin{array}{c}27(44.3) \\
14(23) \\
12(19.7) \\
8(13)\end{array}$ \\
\hline \multicolumn{4}{|l|}{ Specific metastatic sites, $\boldsymbol{n}(\%)$} \\
\hline $\begin{array}{l}\text { Lung } \\
\text { Liver } \\
\text { Bone }\end{array}$ & $\begin{aligned} 22 & (57.9) \\
2 & (5.3) \\
20 & (52.6)\end{aligned}$ & $\begin{array}{c}11(47.8) \\
2(8.7) \\
9(39.1)\end{array}$ & $\begin{array}{c}33(54.1) \\
4(6.6) \\
29(47.5)\end{array}$ \\
\hline \multicolumn{4}{|l|}{ MSKCC prognostic risk, n (\%) } \\
\hline $\begin{array}{l}\text { Low risk } \\
\text { Intermediate risk } \\
\text { High risk }\end{array}$ & $\begin{array}{r}5(13.2) \\
28(73.6) \\
5(13.2)\end{array}$ & $\begin{array}{r}5(21.7) \\
13(56.6) \\
5(21.7)\end{array}$ & $\begin{array}{l}10(16.4) \\
41(67.2) \\
10(16.4)\end{array}$ \\
\hline \multicolumn{4}{|l|}{ Heng prognostic group, $\mathbf{n}(\%)$} \\
\hline $\begin{array}{l}\text { Favourable } \\
\text { Intermediate } \\
\text { Poor }\end{array}$ & $\begin{array}{r}5(13.2) \\
23(60.5) \\
10(26.3)\end{array}$ & $\begin{array}{r}5(21.7) \\
13(56.6) \\
5(21.7)\end{array}$ & $\begin{array}{l}10(16.4) \\
36(59) \\
15(24.6)\end{array}$ \\
\hline Weight (kg), median (range) & $78(50-124)$ & $62(44-91)$ & $73(44-124)$ \\
\hline BMI $\left(\mathrm{kg} \mathrm{m}^{-2}\right)$, median (range) & $25.9(17.3-43.4)$ & $24.2(17.1-36.5)$ & $24.9(17.1-43.4)$ \\
\hline Underweight (BMI<18.5), n (\%) & $2(5.3)$ & $3(13)$ & $5(8.2)$ \\
\hline 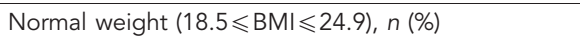 & $14(36.8)$ & $13(56.5)$ & $27(44.3)$ \\
\hline Overweight $(25 \leqslant \mathrm{BMI} \leqslant 29.9), \mathrm{n}(\%)$ & $12(31.6)$ & $4(17.5)$ & $16(26.2)$ \\
\hline Obese $(30 \leqslant B M I), n(\%)$ & $10(26.3)$ & $3(13)$ & $13(21.3)$ \\
\hline LBM (kg), median (range) & $49.3(32.2-65.9)$ & $33.3(24.9-40.3)$ & $42.7(24.9-65.9)$ \\
\hline Skeletal muscle L3 area $\left(\mathrm{cm}^{2}\right)$, median (range) & $158(101-214)$ & $105(77-128)$ & $136(77-214)$ \\
\hline Skeletal muscle L3 index $\left(\mathrm{cm}^{2} \mathrm{~m}^{-2}\right)$, median (range) & $51.6(35.0-67.5)$ & $40.9(27.2-47.2)$ & $46.2(27.2-67.5)$ \\
\hline Sarcopenic, n (\%) & $24(63.2)$ & $8(34.8)$ & $32(52.5)$ \\
\hline Sarcopenic and BMI <25, $n(\%)$ & $13(34.2)$ & $7(30.4)$ & $20(32.8)$ \\
\hline
\end{tabular}




\begin{tabular}{|c|c|c|c|c|c|c|}
\hline Patient & Starting dose & Grade 3 toxicities & Grade 2 toxicities & $\begin{array}{c}\text { Sarcopenia and } \\
\text { BMI }<25\end{array}$ & Therapy adjustment & $\begin{array}{l}\text { Sunitinib after } \\
\text { DLT (weeks) }\end{array}$ \\
\hline 1 & $37.5 \mathrm{mg} C D D$ & Proteinuria & 0 & No & $37.5 \mathrm{mg}$ CDD & 6 \\
\hline 2 & $\begin{array}{l}25 \mathrm{mg} C D D \text { and } 37.5 \mathrm{mg} \\
\mathrm{CDD} \text { after } 2 \text { weeks }\end{array}$ & 0 & $\begin{array}{l}\text { Nausea } \\
\text { Proteinuria } \\
\text { Hypertension } \\
\text { Asthenia }\end{array}$ & Yes & $37.5 \mathrm{mg}$ CDD & 8 \\
\hline 3 & $50 \mathrm{mg} 4 \mathrm{w} / 6$ & Thrombocytopenia & Hypertension & Yes & $37.5 \mathrm{mg}$ CDD & 50 \\
\hline 4 & $50 \mathrm{mg} 4 \mathrm{w} / 6$ & MAHA & Asthenia & Yes & PT, switch to temsirolimus & 0 \\
\hline 5 & $50 \mathrm{mg} \mathrm{4w/6}$ & $\begin{array}{l}\text { Hypothyroidism } \\
\text { Asthenia }\end{array}$ & 0 & Yes & PT, switch to everolimus & 0 \\
\hline 6 & $50 \mathrm{mg} 4 \mathrm{w} / 6$ & Hypertension & Proteinuria & No & $37.5 \mathrm{mg}$ CDD & 37 (ongoing) \\
\hline 7 & $37.5 \mathrm{mg} C D D$ & $\begin{array}{l}\text { Hand-foot syndrome } \\
\text { Stomatitis }\end{array}$ & Diarrhoea & No & $25 \mathrm{mg}$ CDD & 21 \\
\hline 8 & $37.5 \mathrm{mg} C D D$ & Asthenia & 0 & No & $25 \mathrm{mg}$ CDD & 150 \\
\hline 9 & $50 \mathrm{mg} \mathrm{4w/6}$ & Stomatitis & Thrombocytopenia & No & $37.5 \mathrm{mg}$ CDD & 22 \\
\hline 10 & $50 \mathrm{mg} \mathrm{4w/6}$ & $\begin{array}{l}\text { Proteinuria } \\
\text { MAS }\end{array}$ & Asthenia & No & $50 \mathrm{mg} 4 \mathrm{w} / 6$ & 33 \\
\hline 11 & $50 \mathrm{mg} \mathrm{4w/6}$ & $\begin{array}{l}\text { Asthenia } \\
\text { TMA }\end{array}$ & 0 & Yes & PT & 0 \\
\hline 12 & $50 \mathrm{mg} \mathrm{4w/6}$ & $\begin{array}{l}\text { TMA } \\
\text { RPLS }\end{array}$ & $\begin{array}{l}\text { Hypertension } \\
\text { Asthenia }\end{array}$ & Yes & PT, switch to temsirolimus & 0 \\
\hline 13 & $25 \mathrm{mg}$ CDD & Hypertension & $\begin{array}{l}\text { Stomatitis } \\
\text { Hypothyroidism } \\
\text { Edema }\end{array}$ & Yes & PT, switch to everolimus & 0 \\
\hline 14 & $50 \mathrm{mg} \mathrm{4w/6}$ & $\begin{array}{l}\text { Stomatitis } \\
\text { Rash }\end{array}$ & 0 & Yes & $37.5 \mathrm{mg} \mathrm{CDD}$ & 16 (ongoing) \\
\hline 15 & $50 \mathrm{mg} 4 \mathrm{w} / 6$ & Haemorrhagic rectocolitis & 0 & No & PT, switch to sorafenib & 0 \\
\hline 16 & $50 \mathrm{mg} \mathrm{4w/6}$ & $\begin{array}{l}\text { Asthenia } \\
\text { Anorexia }\end{array}$ & Proteinuria & No & $25 \mathrm{mg}$ CDD & 31 \\
\hline 17 & $50 \mathrm{mg} \mathrm{4w/6}$ & $\begin{array}{l}\text { RLPS } \\
\text { Asthenia }\end{array}$ & 0 & Yes & PT & 0 \\
\hline 18 & $50 \mathrm{mg} \mathrm{4w/6}$ & Nausea & $\begin{array}{l}\text { Hypertension } \\
\text { Hand-foot syndrome } \\
\text { Asthenia }\end{array}$ & Yes & $37.5 \mathrm{mg}$ CDD & 85 \\
\hline
\end{tabular}

patients in the remaining patients (median duration: 31 weeks, range 6-150), $P=0.06$.

The comparison of anthropometric parameters between patients with or without early DLT is summarised in Table 3. Significant differences were observed regarding age $(P=0.006)$, weight $(P=0.007)$, BSA $(P=0.004), \operatorname{LBM}(P=0.006)$ and skeletal muscle L3 index $(P=0.02)$. No difference was found regarding BMI or sarcopenia. The prevalence of DLT did not significantly differ in patients receiving $50 \mathrm{mg}, 4$ weeks/6, or CDD $<50$ mgper day $(P=0.31)$.

The comparison between patients with both sarcopenia and BMI $<25 \mathrm{~kg} \mathrm{~m}^{-2}$ with the remaining patients is summarised in Table 4. No difference was found regarding the starting dose, ECOG PS at beginning of treatment or classification according to the MSKCC risk group. Figures $2 \mathrm{~A}$ and B illustrate the distribution of BMI, muscle index and early DLT for men and women, respectively. Overall, sarcopenic patients with BMI $<25 \mathrm{~kg} \mathrm{~m}^{-2}$ experienced significantly more DLTs $(P=0.01$; odds ratio $=4.1$; 95\% CI: (1.3-13.3)), more cumulative grade 2 or 3 toxicities
$(P=0.008)$ and more grade 3 toxicities $(P=0.04)$ during the first cycle. Permanent termination of sunitinib during the first cycle occurred in $30 \%$ of these patients compared with $2.4 \%$ of the remaining patients $(P=0.01)$. Of note, acute vascular toxicities (microangiopathic haemolytic anaemia, thrombotic microangiopathy or reversible posterior leukoencephalopathy syndrome) were more frequent during the first cycle of treatment in this subset of patients $(P=0.009)$. By multivariate analysis, the combination of sarcopenia and $\mathrm{BMI}<25 \mathrm{~kg} \mathrm{~m}^{-2}$ was the only independent predictor of early DLTs $(P=0.04)$.

Survival analysis. The median PFS and OS for the study population $(n=61)$ were 9.0 (95\% CI: 6.4-11.8) and 22.1 months (95\% CI: 14.0-26.0), respectively. No significant differences were observed between patients with sarcopenia and $\mathrm{BMI}<25 \mathrm{~kg} \mathrm{~m}^{-2}$, and the remaining patients regarding median PFS $(7.5$ (95\% CI: 3.9-10.1) vs 9.4 months (95\% CI: 6.3-16.2), respectively; $P=0.11$; Figure 3A) and median OS (19.3 (95\% CI: 14-20) vs 23.5 months (95\% CI: 12.5-40.7), respectively; $P=0.21$; Figure 3B). When 


\begin{tabular}{|c|c|c|c|}
\hline Variable & $\begin{array}{l}\text { Patients } \\
\text { with early } \\
\text { DLT, } \\
\text { mean } \\
\text { (s.d.) }\end{array}$ & $\begin{array}{l}\text { Patients } \\
\text { without } \\
\text { early } \\
\text { DLT, mean } \\
\text { (s.d.) }\end{array}$ & $P$-value \\
\hline Females & $n=9$ & $n=14$ & \\
\hline Age (years) & $62(14)$ & $56(12)$ & 0.17 \\
\hline Weight (kg) & $62(12)$ & $66(13)$ & 0.39 \\
\hline $\mathrm{BMI}\left(\mathrm{kg} \mathrm{m}^{-2}\right)$ & $24.4(5.1)$ & $24.5(5)$ & 0.59 \\
\hline BSA $\left(m^{2}\right)$ & $1.66(0.15)$ & $1.73(0.19)$ & 0.18 \\
\hline LBM (kg) & $30.6(3.8)$ & $35.3(3.3)$ & 0.01 \\
\hline $\begin{array}{l}\text { Skeletal muscle } \\
\text { L3 index }\left(\mathrm{cm}^{2} \mathrm{~m}^{-2}\right)\end{array}$ & $37.7(6.5)$ & 41.4 (4) & 0.17 \\
\hline Sarcopenia, n (\%) & $5(55.5)$ & $3(21.4)$ & 0.17 \\
\hline $\begin{array}{l}\text { Sarcopenia and } \\
\text { BMI }<25 \mathrm{~kg} \mathrm{~m}^{-2}, \mathrm{n}(\%)\end{array}$ & $5(55.5)$ & $2(14.2)$ & 0.06 \\
\hline Males & $n=9$ & $n=29$ & \\
\hline Age (years) & $65.8(6.2)$ & $57(12)$ & 0.01 \\
\hline Weight (kg) & $72(14)$ & $86(17)$ & 0.03 \\
\hline BMI $\left(\mathrm{kg} \mathrm{m}^{-2}\right)$ & $24.8(5.3)$ & $27.6(5.4)$ & 0.18 \\
\hline BSA $\left(m^{2}\right)$ & $1.84(0.17)$ & $2.04(0.22)$ & 0.02 \\
\hline LBM (kg) & $44.9(8.4)$ & $50.5(7.1)$ & 0.13 \\
\hline $\begin{array}{l}\text { Skeletal muscle L3 index } \\
\left(\mathrm{cm}^{2} \mathrm{~m}^{-2}\right)\end{array}$ & $49.3(10.4)$ & $52.3(7.3)$ & 0.30 \\
\hline Sarcopenia, n (\%) & $7(77.8)$ & $17(58.6)$ & 0.43 \\
\hline $\begin{array}{l}\text { Sarcopenia and } \\
\text { BMI }<25 \mathrm{~kg} \mathrm{~m}^{-2}, \mathrm{n}(\%)\end{array}$ & $5(55.5)$ & $8(27.6)$ & 0.22 \\
\hline Total & $n=18$ & $n=43$ & \\
\hline Age (years) & 64 (11) & $56(12)$ & 0.006 \\
\hline Weight (kg) & $67.2(13.4)$ & $79.4(18.6)$ & 0.007 \\
\hline BMI $\left(\mathrm{kg} \mathrm{m}^{-2}\right)$ & $24.6(5)$ & $26.6(5.4)$ & 0.10 \\
\hline BSA $\left(m^{2}\right)$ & $1.75(0.18)$ & $1.94(0.26)$ & 0.004 \\
\hline LBM (kg) & $37.7(9.7)$ & $45.6(9.4)$ & 0.006 \\
\hline $\begin{array}{l}\text { Skeletal muscle L3 index } \\
\left(\mathrm{cm}^{2} \mathrm{~m}^{-2}\right)\end{array}$ & $43.5(10.3)$ & $48.7(8.2)$ & 0.02 \\
\hline Sarcopenia, n (\%) & $12(66.7)$ & $20(46.5)$ & 0.17 \\
\hline $\begin{array}{l}\text { Sarcopenia and } \\
\mathrm{BMl}<25 \mathrm{~kg} \mathrm{~m}^{-2}, \mathrm{n}(\%)\end{array}$ & $10(55.5)$ & $10(23.3)$ & 0.01 \\
\hline \multicolumn{4}{|c|}{$\begin{array}{l}\text { Abbreviations: } \mathrm{DLT}=\text { dose-limiting toxicities; } \mathrm{BMI}=\text { body mass index; } \mathrm{BSA}=\text { body surface } \\
\text { area; } \mathrm{LBM}=\text { lean body mass. Bold entries indicate statistically significant values }(P<0.05) \text {. }\end{array}$} \\
\hline
\end{tabular}

considering sarcopenic and non-sarcopenic patients, no significant differences were observed regarding PFS $(P=0.71)$ or OS $(P=0.75)$.

\section{DISCUSSION}

This retrospective analysis is the first evaluating the relationship between sarcopenia and early toxicity in patients treated with sunitinib for mRCC. We found that patients with sarcopenia and a $\mathrm{BMI}<25 \mathrm{~kg} \mathrm{~m}^{-2}$ experienced significantly more DLTs, more cumulative grade 2 or 3 toxicities and more grade 3 toxicities during the first cycle.

Baseline characteristics of patients included in this analysis were similar to those observed in previous studies in mRCC patients
(Antoun et al, 2010a,b). Indeed, sarcopenic patients and sarcopenic patients with low BMI represented $52.5 \%$ and $32.8 \%$, respectively, of all patients in the present cohort. A high proportion of patients experienced early DLTs, probably reflecting the toxicity profile of sunitinib in less-selected patients than those included in clinical trials. We found that low skeletal muscle area (and, therefore, low LBM) was significantly associated with the occurrence of early DLTs $(P=0.006)$, but sarcopenia per se was not predictive for early DLTs $(P=0.17)$.

Antoun et al (2010a) observed that BMI $<25 \mathrm{~kg} \mathrm{~m}^{-2}$ associated with sarcopenia was a significant predictor of toxicity in mRCC patients treated with sorafenib. Hence, further analyses combining sarcopenia with low BMI were pre-planned. This subset of patients was found to be at particular risk of DLT during the first cycle, with $50 \%$ of patients experiencing a DLT, compared with $19.5 \%$ among other patients $(P=0.01)$. This difference was related to the occurrence of more cumulative grade 2 or 3 toxicities, more cumulative grade 3 toxicities and more acute vascular toxicities. The sum of several toxicities, which were not individually dose limiting, lead to permanent termination of sunitinib in six patients (30\%) with sarcopenia and BMI $<25 \mathrm{~kg} \mathrm{~m}^{-2}$, compared with only one patient $(2.4 \%)$ in the remaining group $(P=0.003)$.

Remarkably, the excessive toxicity observed in patients with sarcopenia and BMI $<25 \mathrm{~kg} \mathrm{~m}^{-2}$ did not translate into a significantly poorer PFS or poorer OS. The first explanation could lie in the fact that, following the occurrence of a DLT sunitinib was resumed in up to $40 \%$ of patients with sarcopenia and low BMI, for a median time of 33 weeks (range 16-85).

The second potential explanation is that efficient second-line treatment was given to five of the seven patients in whom sunitinib had been permanently withdrawn.

The excessive toxicity in patients with both sarcopenia and low BMI observed in this series is in line with previous findings, indicating that both conditions underlie a particular vulnerability to various anti-cancer agents.

An association between low BMI and increased toxicity has been reported in a population of 45 patients ( $85 \%$ with mRCC) treated with sunitinib (Telli et al, 2008). In this population, grade 3 or 4 cardiotoxicity was associated with low BMI (mean $23.9 \mathrm{~kg} \mathrm{~m}^{-2}$ vs $\left.27.1 \mathrm{~kg} \mathrm{~m}^{-2} ; P=0.03\right)$.

Sunitinib toxicity has also been associated with low BSA (a variable conditioned to height and weight, similar to BMI) in 82 advanced RCC patients treated with sunitinib (van der Veldt et al, 2008). In this population, DLTs occurred in 37 patients and were significantly related to low BSA $(P=0.005)$. Interestingly, low BSA was also significantly associated with early DLT $(P=0.002)$ in the present series.

Sarcopenia is associated with an increased toxicity of 5-fluorouracil (Prado et al, 2007), capecitabine (Prado et al, 2009), epiribucin (Prado et al, 2011) and sorafenib (Mir et al, 2012). Sarcopenia is also associated with poorer survival for obese patients with solid tumours of the lung or gastro-intestinal tract (Prado et al, 2008), and with increased propensity for nosocomial infection and other complications (Cosqueric et al, 2006).

Finally, an increased toxicity could also be linked to higher drug exposure, in the same way it has been suggested for hepatocellular carcinoma sarcopenic patients treated with sorafenib (Mir et al, 2012). Indeed, in the phase I trial of sunitinib (Faivre et al, 2006) most patients with DLT had combined sunitinib and SU012662 (sunitinib major metabolite) through plasma concentrations $\geqslant 100 \mathrm{ng} \mathrm{ml}^{-1}$.

The main limitations of our study are its retrospective nature and the relatively small number of patients included, which could potentially have biased survival analyses. However, our findings have potentially direct bedside implications, as evaluating sarcopenia on CT scan and BMI calculation are feasible in daily practice. This would enable closer follow-up of patients at risk and, 


\section{Table 4. Comparison between patients with or without sarcopenia and $\mathrm{BMl}<25 \mathrm{~kg} \mathrm{~m}^{-2}$, and outcome during first cycle of treatment}

\begin{tabular}{|c|c|c|c|}
\hline & $\begin{array}{c}\text { Sarcopenic and } \\
\mathrm{BMI}<25 \mathrm{~kg} \mathrm{~m}^{-2}(\mathrm{n}=20)\end{array}$ & $\begin{array}{c}\text { Non-sarcopenic or } \\
\mathrm{BMI}>25 \mathrm{~kg} \mathrm{~m}^{-2}(n=41)\end{array}$ & $P$-value \\
\hline \multicolumn{4}{|l|}{ Sunitinib starting dose, $n(\%)$} \\
\hline $\begin{array}{l}25 \text { or } 37.5 \mathrm{mg}, \mathrm{CDD} \\
50 \mathrm{mg}, 4 \text { weeks } / 6\end{array}$ & $\begin{array}{r}2(10) \\
18(90)\end{array}$ & $\begin{array}{l}10(24.4) \\
31(75.6)\end{array}$ & 0.30 \\
\hline \multicolumn{4}{|l|}{ ECOG PS, $\boldsymbol{n}(\%)$} \\
\hline $\begin{array}{l}0-1 \\
\geqslant 2\end{array}$ & $\begin{array}{r}14(70) \\
6(30)\end{array}$ & $\begin{aligned} 36(87.8) \\
5(12.2)\end{aligned}$ & 0.15 \\
\hline \multicolumn{4}{|l|}{ MSKCC prognostic score, $n$ (\%) } \\
\hline $\begin{array}{l}\text { Low risk } \\
\text { Intermediate risk } \\
\text { High risk }\end{array}$ & $\begin{array}{r}2(10) \\
13(65) \\
5(25)\end{array}$ & $\begin{array}{r}8(19.5) \\
28(68.3) \\
5(12.2)\end{array}$ & 0.39 \\
\hline \multicolumn{4}{|l|}{ Heng prognostic score, $\boldsymbol{n}(\%)$} \\
\hline $\begin{array}{l}\text { Favourable } \\
\text { Intermediate } \\
\text { Poor }\end{array}$ & $\begin{array}{c}1(5) \\
11(55) \\
8(40)\end{array}$ & $\begin{array}{r}9(22) \\
25(61) \\
7(17)\end{array}$ & 0.07 \\
\hline \multicolumn{4}{|l|}{ Characteristics, median (range) } \\
\hline $\begin{array}{l}\text { Age (years) } \\
\text { Weight }(\mathrm{kg}) \\
\text { Height }(\mathrm{m}) \\
\text { BMI }\left(\mathrm{kg} \mathrm{m}^{-2}\right) \\
\text { BSA }\left(\mathrm{m}^{2}\right) \\
\text { Haemoglobin }\left(\mathrm{g} \mathrm{dl}^{-1}\right) \\
\text { Lymphocytes }\left(\times 10^{6} / \mathrm{l}\right) \\
\text { Platelets }\left(\times 10^{9} / \mathrm{l}\right) \\
\text { Albuminaemia }\left(\mathrm{gl}^{-1}\right) \\
\text { CRP }\left(\mathrm{gl} \mathrm{I}^{-1}\right) \\
\text { Creatininaemia }(\mu \mathrm{m}) \\
\text { Lumbar skeletal muscle index }\left(\mathrm{cm}^{2} \mathrm{~m}^{-2}\right) \\
\text { LBM }(\mathrm{kg})\end{array}$ & $\begin{array}{c}61(35-79) \\
64(50-79) \\
1.73(1.58-1.87) \\
23.0(17.3-24.9) \\
1.75(1.54-1.99) \\
12.1(7.2-15.2) \\
1545(310-2110) \\
361(222-725) \\
40(26-46) \\
32.5(1-147.1) \\
84.5(45-136.3) \\
41.4(27.2-54.5) \\
42.0(24.9-53.1)\end{array}$ & $\begin{aligned} 58 & (29-83) \\
78 & (44-124) \\
1.70 & (1.50-1.92) \\
27.1 & (17.1-43.4) \\
1.96 & (1.39-2.53) \\
12.7 & (8.4-16.6) \\
1400 & (560-4872) \\
271 & (124-517) \\
39 & (28-45) \\
18 & (1-298) \\
98.5 & (53-167.3) \\
47.7 & (37.7-67.5) \\
46.7 & (32.3-65.9)\end{aligned}$ & $\begin{array}{l}0.46 \\
0.001 \\
0.44 \\
<0.001 \\
0.009 \\
0.43 \\
0.93 \\
0.06 \\
0.98 \\
0.87 \\
0.02 \\
<0.001 \\
0.01\end{array}$ \\
\hline \multicolumn{4}{|l|}{ DLT, $n(\%)$} \\
\hline $\begin{array}{l}\text { Present } \\
\text { Absent }\end{array}$ & $\begin{array}{l}10(50) \\
10(50)\end{array}$ & $\begin{array}{r}8(19.5) \\
33(80.5)\end{array}$ & 0.01 \\
\hline \multicolumn{4}{|c|}{ Permanent termination of sunitinib owing to toxicity, $\boldsymbol{n}(\%)$} \\
\hline $\begin{array}{l}\text { Present } \\
\text { Absent }\end{array}$ & $\begin{array}{r}6(30) \\
14(70)\end{array}$ & $\begin{array}{c}1(2.4) \\
40(97.6)\end{array}$ & 0.003 \\
\hline \multicolumn{4}{|l|}{ Prevalence of selected toxicities, $\boldsymbol{n}(\%)$} \\
\hline $\begin{array}{l}\text { Diarrhoea, grade } 2-3 \\
\text { Grade } 3 \text { diarrhoea } \\
\text { Hypertension, grade } 2-3 \\
\text { Grade } 3 \text { hypertension } \\
\text { Asthenia, grade } 2-3 \\
\text { Grade } 3 \text { asthenia } \\
\text { Hand-foot syndrome, grade } 2-3 \\
\text { Grade } 3 \text { hand-foot syndrome } \\
\text { Acute vascular toxicity (MAHA, TMA, RPLS), } n(\%) \\
\text { Number of grade } 2 \text { or } 3 \text { toxicities per patient, } n \text { (\%) } \\
0 \\
1 \\
2 \\
3 \\
4 \\
0-1 \\
\geqslant 2 \\
\text { Number of grade } 3 \text { toxicities per patient, } n(\%) \\
0 \\
1 \\
\geqslant 2\end{array}$ & $\begin{array}{l}0 \\
0 \\
12(60) \\
6(30) \\
10(50) \\
3(15) \\
2(10) \\
0 \\
4(20) \\
1(5) \\
5(25) \\
8(40) \\
2(10) \\
4(20) \\
6(30) \\
14(70) \\
6(30) \\
8(40) \\
6(30)\end{array}$ & $\begin{array}{l}4(9.8) \\
0 \\
14(34.1) \\
9(22) \\
16(39) \\
4(9.8) \\
2(4.8) \\
1(2.4) \\
0 \\
13(31.7) \\
11(26.8) \\
11(26.8) \\
6(14.7) \\
0 \\
24(58.5) \\
17(41.5) \\
23(56.1) \\
15(36.6) \\
3(7.3)\end{array}$ & $\begin{array}{c}0.29 \\
1 \\
0.09 \\
0.53 \\
0.58 \\
0.67 \\
0.59 \\
1 \\
0.009 \\
0.008 \\
0.02 \\
1 \\
0.37 \\
1 \\
0.009 \\
0.055 \\
\\
0.04 \\
0.06 \\
1 \\
0.04\end{array}$ \\
\hline
\end{tabular}



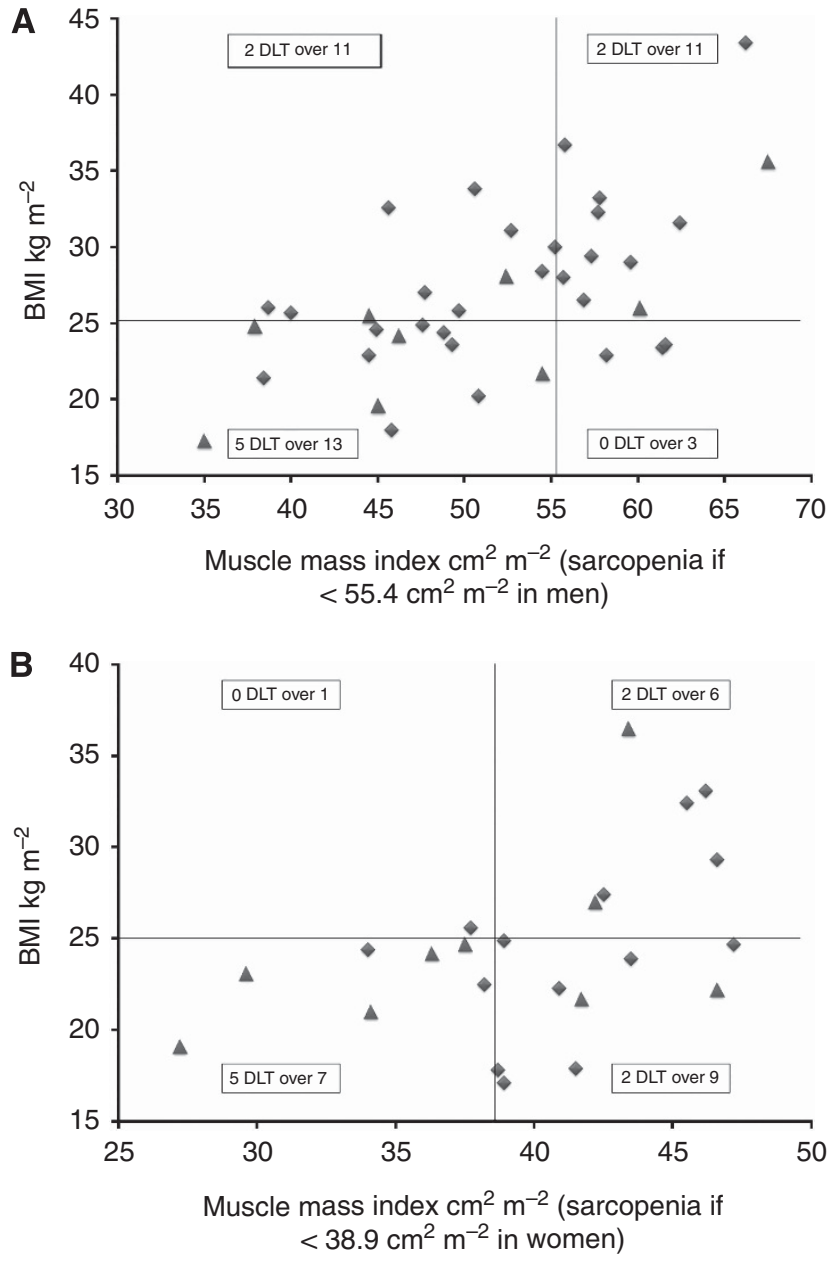

Figure 2. Distribution of BMI, muscle index and early DLT. (A) Distribution of BMI, muscle index and early DLT for men. Symbols represent individual patients, filled triangles represent patients with early DLT. (B) Distribution of BMI, muscle index and early DLT for women. Symbols represent individual patients, filled triangles represent patients with early DLT.

therefore, avoid severe toxicities by early dose adjustments or therapeutic interventions when needed.

Conversely, patients devoid of sarcopenia and BMI $<25 \mathrm{~kg} \mathrm{~m}^{-2}$ could probably be treated with full-dose sunitinib without excessive risk, even when ECOG PS exceeds 1.

In conclusion, our results highlight the importance of assessing body composition, and suggest that the combination of sarcopenia and low BMI predicts early DLTs in mRCC patients treated with sunitinib.

\section{ACKNOWLEDGEMENTS}

We thank Dr Romain Coriat, the nurses, residents and clinical research staff at the Cochin Teaching Hospital.

\section{CONFLICT OF INTEREST}

Dr Mir has acted as an advisory board member for Roche, and has been a paid consultant for Roche, Servier and Pfizer. Dr Ropert has acted as an advisory board member for Sanofi-Aventis and has been a paid consultant for Bayer. Professor Zerbib has acted as an
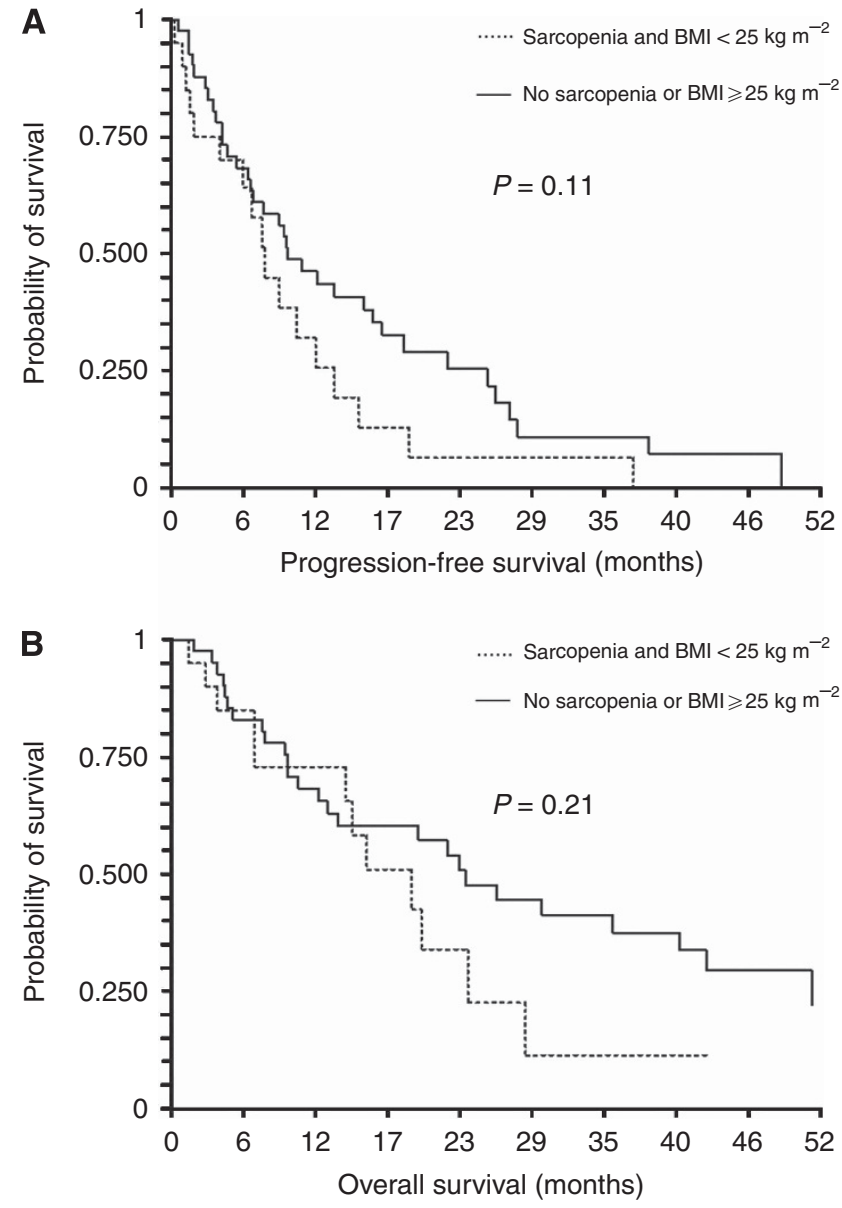

Figure 3. Progression-free survival and overall survival.

(A) Progression-free survival in sarcopenic patients with low BMI compared with remaining patients. (B) Overall survival in sarcopenic patients with low BMI compared with remaining patients.

advisory board member for Sanofi-Aventis, Ferring Pharmaceuticals, Ipsen and Janssen. Professor Goldwasser has acted as a paid consultant for Roche, Amgen, Bayer Healthcare and Pfizer. All other authors declare no conflict of interest.

\section{REFERENCES}

Antoun S, Baracos VE, Birdsell L, Escudier B, Sawyer MB (2010a) Low body mass index and sarcopenia associated with dose-limiting toxicity of sorafenib in patients with renal cell carcinoma. Ann Oncol 21(8): 1594-1598.

Antoun S, Birdsell L, Sawyer MB, Venner P, Escudier B, Baracos VE (2010b) Association of skeletal muscle wasting with treatment with sorafenib in patients with advanced renal cell carcinoma: results from a placebo-controlled study. J Clin Oncol 28(6): 1054-1060.

Barrios CH, Hernandez-Barajas D, Brown MP, Lee SH, Fein L, Liu JH, Hariharan S, Martell BA, Yuan J, Bello A, Wang Z, Mundayat R, Rha SY (2012) Phase II trial of continuous once-daily dosing of sunitinib as first-line treatment in patients with metastatic renal cell carcinoma. Cancer 118(5): 1252-1259.

Chow LQ, Eckhardt SG (2007) Sunitinib: from rational design to clinical efficacy. J Clin Oncol 25(7): 884-896.

Cosqueric G, Sebag A, Ducolombier C, Thomas C, Piette F, Weill-Engerer S (2006) Sarcopenia is predictive of nosocomial infection in care of the elderly. Br J Nutr 96(5): 895-901.

Cruz-Jentoft AJ, Baeyens JP, Bauer JM, Boirie Y, Cederholm T, Landi F, Martin FC, Michel JP, Rolland Y, Schneider SM, Topinkova E, 
Vandewoude M, Zamboni M (2010) Sarcopenia: European consensus on definition and diagnosis: report of the European Working Group on sarcopenia in older people. Age Ageing 39(4): 412-423.

Escudier B, Roigas J, Gillessen S, Harmenberg U, Srinivas S, Mulder SF, Fountzilas G, Peschel C, Flodgren P, Maneval EC, Chen I, Vogelzang NJ (2009) Phase II study of sunitinib administered in a continuous once-daily dosing regimen in patients with cytokine-refractory metastatic renal cell carcinoma. J Clin Oncol 27(25): 4068-4075.

Faivre S, Delbaldo C, Vera K, Robert C, Lozahic S, Lassau N, Bello C, Deprimo S, Brega N, Massimini G, Armand JP, Scigalla P, Raymond E (2006) Safety, pharmacokinetic, and antitumor activity of SU11248, a novel oral multitarget tyrosine kinase inhibitor, in patients with cancer. J Clin Oncol 24(1): 25-35.

Fearon K, Strasser F, Anker SD, Bosaeus I, Bruera E, Fainsinger RL, Jatoi A, Loprinzi C, MacDonald N, Mantovani G, Davis M, Muscaritoli M, Ottery F, Radbruch L, Ravasco P, Walsh D, Wilcock A, Kaasa S, Baracos VE (2011) Definition and classification of cancer cachexia: an international consensus. Lancet Oncol 12(5): 489-495.

Garcia-Donas J, Esteban E, Leandro-Garcia LJ, Castellano DE, del Alba AG, Climent MA, Arranz JA, Gallardo E, Puente J, Bellmunt J, Mellado B, Martinez E, Moreno F, Font A, Robledo M, Rodriguez-Antona C (2011) Single nucleotide polymorphism associations with response and toxic effects in patients with advanced renal-cell carcinoma treated with first-line sunitinib: a multicentre, observational, prospective study. Lancet Oncol 12(12): 1143-1150.

Gupta K, Miller JD, Li JZ, Russell MW, Charbonneau C (2008) Epidemiologic and socioeconomic burden of metastatic renal cell carcinoma (mRCC): a literature review. Cancer Treat Rev 34(3): 193-205.

Heymsfield SB, Wang Z, Baumgartner RN, Ross R (1997) Human body composition: advances in models and methods. Annu Rev Nutr 17: 527-558.

Izzedine H, Ederhy S, Goldwasser F, Soria JC, Milano G, Cohen A, Khayat D, Spano JP (2009) Management of hypertension in angiogenesis inhibitortreated patients. Ann Oncol 20(5): 807-815.

Mir O, Coriat R, Blanchet B, Durand JP, Boudou-Rouquette P, Michels J, Ropert S, Vidal M, Pol S, Chaussade S, Goldwasser F (2012) Sarcopenia predicts early dose-limiting toxicities and pharmacokinetics of sorafenib in patients with hepatocellular carcinoma. PLoS One 7(5): e37563.

Mitsiopoulos N, Baumgartner RN, Heymsfield SB, Lyons W, Gallagher D, Ross R (1998) Cadaver validation of skeletal muscle measurement by magnetic resonance imaging and computerized tomography. J Appl Physiol 85(1): 115-122.

Motzer RJ, Hutson TE, Tomczak P, Michaelson MD, Bukowski RM, Oudard S, Negrier S, Szczylik C, Pili R, Bjarnason GA, Garcia-del-Muro X, Sosman JA, Solska E, Wilding G, Thompson JA, Kim ST, Chen I, Huang X, Figlin RA (2009) Overall survival and updated results for sunitinib compared with interferon alfa in patients with metastatic renal cell carcinoma. J Clin Oncol 27(22): 3584-3590.

Motzer RJ, Hutson TE, Tomczak P, Michaelson MD, Bukowski RM, Rixe O, Oudard S, Negrier S, Szczylik C, Kim ST, Chen I, Bycott PW, Baum CM, Figlin RA (2007) Sunitinib versus interferon alfa in metastatic renal-cell carcinoma. N Engl J Med 356(2): 115-124.
Mourtzakis M, Prado CM, Lieffers JR, Reiman T, McCargar LJ, Baracos VE (2008) A practical and precise approach to quantification of body composition in cancer patients using computed tomography images acquired during routine care. Appl Physiol Nutr Metab 33(5): $997-1006$

Prado CM, Baracos VE, McCargar LJ, Mourtzakis M, Mulder KE, Reiman T, Butts CA, Scarfe AG, Sawyer MB (2007) Body composition as an independent determinant of 5-fluorouracil-based chemotherapy toxicity. Clin Cancer Res 13(11): 3264-3268.

Prado CM, Baracos VE, McCargar LJ, Reiman T, Mourtzakis M, Tonkin K, Mackey JR, Koski S, Pituskin E, Sawyer MB (2009) Sarcopenia as a determinant of chemotherapy toxicity and time to tumor progression in metastatic breast cancer patients receiving capecitabine treatment. Clin Cancer Res 15(8): 2920-2926.

Prado CM, Lieffers JR, McCargar LJ, Reiman T, Sawyer MB, Martin L, Baracos VE (2008) Prevalence and clinical implications of sarcopenic obesity in patients with solid tumours of the respiratory and gastrointestinal tracts: a population-based study. Lancet Oncol 9(7): 629-635.

Prado CM, Lima IS, Baracos VE, Bies RR, McCargar LJ, Reiman T, Mackey JR, Kuzma M, Damaraju VL, Sawyer MB (2011) An exploratory study of body composition as a determinant of epirubicin pharmacokinetics and toxicity. Cancer Chemother Pharmacol 67(1): 93-101.

Shen W, Punyanitya M, Wang Z, Gallagher D, St-Onge MP, Albu J, Heymsfield SB, Heshka S (2004) Total body skeletal muscle and adipose tissue volumes: estimation from a single abdominal cross-sectional image. J Appl Physiol 97(6): 2333-2338.

Siegel R, Naishadham D, Jemal A (2012) Cancer statistics, 2012. CA Cancer J Clin 62(1): 10-29.

Telli ML, Witteles RM, Fisher GA, Srinivas S (2008) Cardiotoxicity associated with the cancer therapeutic agent sunitinib malate. Ann Oncol 19(9): 1613-1618.

Therasse P, Arbuck SG, Eisenhauer EA, Wanders J, Kaplan RS, Rubinstein L, Verweij J, Van Glabbeke M, van Oosterom AT, Christian MC, Gwyther SG (2000) New guidelines to evaluate the response to treatment in solid tumors. European Organization for Research and Treatment of Cancer, National Cancer Institute of the United States, National Cancer Institute of Canada. J Natl Cancer Inst 92(3): 205-216.

van der Veldt AA, Boven E, Helgason HH, van Wouwe M, Berkhof J, de Gast G, Mallo H, Tillier CN, van den Eertwegh AJ, Haanen JB (2008) Predictive factors for severe toxicity of sunitinib in unselected patients with advanced renal cell cancer. Br J Cancer 99(2): 259-265.

Wilhelm S, Carter C, Lynch M, Lowinger T, Dumas J, Smith RA, Schwartz B, Simantov R, Kelley S (2006) Discovery and development of sorafenib: a multikinase inhibitor for treating cancer. Nat Rev Drug Discov 5(10): $835-844$.

This work is published under the standard license to publish agreement. After 12 months the work will become freely available and the license terms will switch to a Creative Commons AttributionNonCommercial-Share Alike 3.0 Unported License. 